\title{
Empirical Evidence on the Asymmetric Relationship between Bond and REIT Returns
}

\author{
Emmanuel Anoruo ${ }^{1} \&$ Uchenna Elike ${ }^{2}$ \\ ${ }^{1}$ Professor of Economics and Finance, Coppin State University, Baltimore, Maryland, USA \\ ${ }^{2}$ Professor of Economics and Finance, Alabama A\&M University, Normal Alabama, USA \\ Correspondence: Uchenna Elike, Professor of Economics and Finance, Alabama A\&M University, P. O. Box 624, \\ Normal Alabama 35762, USA. Tel: 256-372-8487. E-mail: uchenna.elike@aam.edu
}

Received: April 23, 2015

Accepted: May 19, 2015

Online Published: May 25, 2015

doi:10.5430/ijfr.v6n3p1

URL: http://dx.doi.org/10.5430/ijfr.v6n3p1

\begin{abstract}
This paper examines the asymmetric relationship between bonds and REITs using monthly data from January 1972 through October 2014. In particular, the paper uses the nonlinear Granger causality test developed by Diks and Panchenko to underpin the dynamic interactions between bond yields and REIT returns. The results from the various unit root tests indicate that bond and REIT returns are level stationary. The results from the linear Granger causality test indicate that bond and REIT returns are not causally related. However, the results from the nonlinear Granger causality test results suggest that both bond and REIT returns have causal influence on each other. The results of this study suggest that diversification benefits cannot be attained by combining either all REITs or equity REITs in a portfolio with bonds. However, after the establishment of the 1992 Revenue Reconciliation Act, the results reveal that it is possible for investors to reduce their portfolio risks by combining bonds and mortgage REITs in their portfolios.
\end{abstract}

Keywords: REIT returns, bond yields, nonlinear causality, portfolio, diversification, risks

\section{Introduction}

Managing risk has always been a major concern for portfolio managers and institutional investors. The fluidity in and the mercurial nature of the financial markets, along with their concomitant variability of returns, have pressured portfolio managers and institutional investors alike to constantly search for ways to ameliorate their exposures. Theoretical portfolio management espouses the benefits of establishing diversified portfolios through their risk reduction potentials. Many studies in this area initially focused mainly on stocks but have since expanded to include other financial instruments. Since the 1980s, however, there has been a keen interest and advocacy to recognize the risk-reduction benefits of including real estate in portfolios (Seller, et al. 1999). Specifically, the argument is that real estate is tangible with low volatility, in addition to its robust income generating potential. Ciochetti, et al. (2002) have argued that because of their liquidity, institutional investors should show much interest in REITs. According to NARIEIT data, investment in this sector in the United States grew from \$350 billion in 2000 to \$945 billion in 2007. Meanwhile, with all the growth in the relative proportion of real estate in portfolios in the United States, Elebash and Christianses (1989) have argued that because of improved global transparency and technology, inclusion of real estate from international markets in portfolios could be pertinent to global diversification. A lot of studies in this area, however, have focused on the integration of real estate and stock, thus highlighting the relation of investor sentiment and stock returns [(Fogler, 1984); (Kalberg, el al., 1996)].

Glascock, et al. (2000) investigated the cointegration of US-REIT returns with bonds and equities using the Engle-Granger-tests and the error-correction models for the time period running from 1972 to 1996. They found evidence of cointegration between stocks and REITs after the 1993 tax reform and cointegration between bonds and REITs in the time period before the reform. Based on their results, they concluded that REITs behave like following the 1993 tax reform. Kleiman, et al. (2002) examined the relationship between the real estate markets for Europe, Asia and North America. They found that the three real estate markets are random walk processes and above all, are cointegrated. They therefore concluded based on these results that the three real estate markets are driven by common shocks and as such, investors in international real estate markets cannot derive diversification benefits in the long-run. Newell and Webb (1996) studied the performance of real estate, stocks and bonds in several major international markets. They found that international investors did achieve additional portfolio diversification benefits 
by incorporating real estate investments in their portfolios, despite the existence of significant degree of appraisal-smoothing and intertemporal correlation among international real estate series.

Wilson and Okunev (1999) examined the relationships between the securitized property markets and stock markets of the U.S., U.K. and Australia. They found that the securitized property markets and stock markets of the U.S., U.K. and Australia are segmented. Based on the finding that these markets were segmented they concluded that U.S. investors can achieve substantial diversification benefits by investing in the real estate markets of U.K. and Australia. Hoesli, et al. (2004) conducted a study on the benefits of adding real estate assets in mixed-asset portfolios using unhedged and hedged indexes. They find that domestic and international real estate assets are effective portfolio diversifiers. Cauchie and Hoesli (2004) using the asset pricing models examined the integration of Swiss real estate investment funds with stock and bond markets for the period from 1986 to 2002. They find that Swiss real estate investment funds are more integrated with the stock market than with bonds. Brounen and Eichholtz (2003) examined the diversification potential of property shares for the UK and the US for the period from 1986 to 2002. They find that the correlations between these asset classes have decreased over the years. Based on this finding, they suggested that at a minimum, Sharpe optimal portfolios should contain a real estate share of approximately 10 percent.

Tsai and Chiang (2013) used the threshold error correction model to examine the relationship between REITs and stocks for six Asian/Pacific financial markets including Australia, Japan, Singapore, Taiwan, Korea, and Hong Kong. They find that REIT and stock indices share long run equilibrium relationship for most of the countries under study based on the finding of cointegration between the two series. They also find evidence of causality running from stocks to REITs in all of the Asian/Pacific markets under study. They also find from the threshold error correction model the existence of bidirectional causality between REITs and stocks in both regimes for most of the financial markets under consideration. Yunus (2012) examined the relationships between securitized real estate markets, stock markets and key macroeconomic factors in ten developed nations including the U.S., Canada, Australia, Japan, France, Germany, Italy, the Netherlands, Switzerland, and the United Kingdom They find that the equity real estate markets were cointegrated with their respective stock markets and with the key macroeconomic factors (i.e. the GDP, M1, CPI, and 10-year government bond yield) in the long run. Yunus (2013) used the cointegration techniques to investigate the degree of linkages among four key property types (namely retail, office, industrial, and residential) of eight major countries including Finland, France, Germany, Sweden and Finland, France, Germany and Sweden. She finds evidence of full convergence among the four property sectors for the USA, Canada, Netherlands, and the UK. This finding was interpreted as evidence that limited diversification possibilities exist for investors in these countries. However she finds evidence of partial convergence among the four property sectors of Finland, France, Germany and Sweden.

Olaleye and Ekemode (2014) examined the relationship between real estate equity (property listed stock) and the non-real estate equity (common stock) for Nigeria for the time period running from January 1999 through December 2011. Specifically, they used the Philipps-Perron unit root test to determine the order of integration of the series and the Johansson cointegration procedure to test for long run relationship between the real estate equity and non-real estate equity assets. They find that real estate equity and non-real estate equity assets have one order of integration and cointegrated. Based on these results they conclude that real estate equity in Nigeria behave more like stocks than their underlying real estate assets. They further conclude that investors cannot derive diversification benefit by combining real estate equity and non-real estate assets. Chiang, et al. (2013) used the multivariate GARCH-vech model to examine the time varying relationship between REITs and the stock markets for four Asian markets namely - Taiwan, Hong Kong, Singapore and Japan. They also used the extreme value theory (EVT) to explain the extreme association between REITs and stock markets before and after the 2007 US sub-prime mortgage crisis. They find that REIT markets for the sample countries are positively correlated with the stock markets following the sub-prime mortgage crisis. They also find that the magnitude and the probability of having extreme positive coefficient are greater than those obtainable in normal market conditions. Based on these results, they concluded that REITs may after all, not act as good hedging instruments during financial crises.

Serrano and Hoesli (2012) using fractional cointegration analysis examined the long run relationship between equity real estate and three sets of variables (including long-term government and corporate bonds) which are often touted in the literature as the drivers of securitized real estate returns. The sample countries include the United States, the United Kingdom and Australia. They find evidence of fractional cointegration between equity real estate and the three sets of variables. Westerheide (2006) investigated the relationship between equity real estate asset and other non-real estate equity asset classes for the U.S., Canada, Australia, Japan, the Netherlands, Belgium, France and Germany for the time period running from 1990 through 2004. They find that real estate securities for most of the 
sample countries had a significantly high performance in both nominal and real terms. They however find little evidence in support of cointegration between bonds and real estate securities.

From the preceding studies, it is obvious that most of the earlier studies have examined the relationship between bonds and REIT returns using either correlation analysis or linear Granger causality tests. A number of studies including Baek and Brock (1992) and Hiemstra and Jones (1994, HJ hereafter) have shown that the standard Granger causality tests tend to have low power in detecting nonlinear causal relationships. Unlike the previous studies, this paper uses longer time series and theoretical consistent frameworks to explore the causal relationship between bonds and REIT returns. In particular, the paper applied the Diks and Panchenko (2006, hereafter DP) framework which unlike the traditional Granger causality test, has the ability to detect nonlinear causal relationships between variables.

The remainder of the paper is structured as follows. Section 2 furnishes the econometric techniques of the study. Section 3 discusses the data and the descriptive statistics. Section 4 details the empirical results. Section 5 presents the conclusions and implications of the study.

\section{Methodology}

This section discusses the methodology of the study. The study begins the empirical analysis by first using the modified Dickey-Fuller (Elliot, et al. 1996) and the Phillips-Perron (Phillips-Perron, 1988) unit root procedures to ascertain the time series properties of changes in consumer sentiment and the REIT returns. In the interest of brevity, these unit root procedures will not be discussed as they have been extensively used in the literature. For nonlinear unit root testing, this paper applies both KSS (Kapetanios, et al., 2003) and Kruse (2012) procedures.

\subsection{Linear Granger Causality Test}

The linear causality test between bond yields and REIT returns is based on Granger (1969). The following VAR models are estimated to determine the direction of causality between bond yields and REIT returns:

$$
\begin{aligned}
& B Y_{\mathrm{t}}=\alpha+\sum_{\mathrm{i}=1}^{\mathrm{a}} \beta_{\mathrm{i}} B Y_{t-i}+\sum_{\mathrm{j}=1}^{\mathrm{b}} \phi_{\mathrm{j}} R R_{t-1}+\mathrm{t} \\
& R R_{\mathrm{t}}=\alpha+\sum_{\mathrm{i}=1}^{\mathrm{a}} \beta_{\mathrm{i}} R R_{\mathrm{t}}-\mathrm{i}+\sum_{\mathrm{j}=1}^{\mathrm{b}} \phi_{\mathrm{j}} B Y_{t-1}+\mathrm{t}
\end{aligned}
$$

where BY represents 10-year treasury bond yields (GS10), RR stands for REIT returns [i.e. all (ALR), equity (EQR) and mortgage (MOR) REIT returns], $\mu$ is the error term, $a$ and $b$ are the maximum lag lengths to be determined by the Akaike Information Criterion. In equation (1), REIT returns Granger-cause bond yields (BY), if the regression coefficients on RR are jointly statistically different from zero. Similarly, in equation (2), the null hypothesis that REIT returns do not Granger-cause bond yields (BY) is rejected if the regression coefficients on RR are jointly statistical significant at the conventional levels. The joint significance of the regression coefficients in equations (1) and (2) is tested through the $F$-statistic.

\subsection{BDS Nonlinearity Test}

This study applies the BDS nonlinearity test developed by Brock et al. (1987, 1996). The BDS nonlinearity test statistic is given by:

$$
\mathrm{W}_{\mathrm{m}}(\varepsilon, \mathrm{T})=\frac{\sqrt{\mathrm{T}}\left[\mathrm{C}_{\mathrm{m}}(\varepsilon, \mathrm{T})-\mathrm{C}_{\mathrm{A}}(\varepsilon, \mathrm{T})^{\mathrm{m}}\right]}{\sigma_{\mathrm{m}}(\varepsilon, \mathrm{T})}
$$

where $\mathrm{W}_{\mathrm{m}}(\varepsilon, \mathrm{T})$ is the BDS test statistic, $\sigma_{\mathrm{m}}(\varepsilon, T)$ represents the standard deviation of $\mathrm{C}_{\mathrm{m}}(\varepsilon, T)$, $m$ stands for the embedding dimension, and $\varepsilon$ is the maximum difference between pairs of observations taken into consideration in calculating the correlation integral. By assumption, the BDS test statistic is asymptotically normally distributed with zero mean and unit variance [i.e. $N(0,1)]$. The null hypothesis under the BDS test is that the series of interest is independently, identically distributed (i.i.d). The linearity hypothesis is rejected provided the computed test statistic is greater the critical value at the convention levels. The rejection of the null hypothesis indicates that the series of interest is a nonlinear process.

\subsection{The Nonparametric Diks-Panchenko Causality Test}

The standard Granger causality test is basically designed to detect linear causal relationship relationships between variables. Simply put, the conventional Granger causality test lacks the ability to account for the presence of 
nonlinear causal relationships between variables. The linear Granger causality test does not account for nonlinear causal relationships among the variables. To address the issue of nonlinear causality, this paper applies the DP nonparametric test. The DP nonlinear Granger causality represents an improvement over the HJ nonlinear causality test. According to Diks and Panchenko, the HJ nonlinear causality test tends to over reject the null hypothesis of non-causality, in particular when the values of $\varepsilon$ are small. A brief discussion of the DP framework follows. The null hypothesis of the Granger test for non-Granger causality from $\mathrm{X}$ to $\mathrm{Y}$ is that $\mathrm{X}_{\mathrm{t}}^{\mathrm{lx}}$ does not contain additional information about $\mathrm{Y}_{\mathrm{t}+1}$. This null hypothesis can be stated mathematically as follows:

$$
\mathrm{H}_{0}: \mathrm{Y}_{\mathrm{t}+1}\left|\left(\mathrm{X}_{\mathrm{t}}^{1 \mathrm{x}} ; \mathrm{Y}_{\mathrm{t}}^{\mathrm{ly}}\right) \sim \mathrm{Y}_{\mathrm{t}+1}\right| \mathrm{Y}_{\mathrm{t}}^{\mathrm{ly}}
$$

where $1_{x}$ and $1_{y}$ are the respective lags of stationary variables X and Y. Diks and Panchenko (2006) modified the Hiemstra and Jones (1994) nonlinear causality test in terms of ratios of joint distributions of $\left(X_{t}, Y_{t}, X_{t+1}\right)$. This relationship is given by:

$$
\frac{f_{x t, y t, x t+1}\left(X_{t}, Y_{t}, X_{t+1}\right)}{f_{x t}, y_{t}\left(X_{t}, Y_{t}\right)}=\frac{f_{x t}, x_{t}+1}{f_{x t}\left(X_{t}, X_{t+1}\right)}
$$

Diks and Panchenko (2006) contend that Hiemstra and Jones (1994) nonlinear causality test tends to the null hypothesis of Granger non-causality, particularly when the values of $\varepsilon$ are small. To overcome the over rejection problem associated with the Hiemstra and Jones (1994) framework, Diks and Panchenko (2006) re-specified null hypothesis of equation (5) as:

$$
E\left[\left(\frac{f_{x t, y t, x_{t+1}}\left(X_{t}, Y_{t}, X_{t+1}\right)}{f_{x t}, y_{t}\left(X_{t}, Y_{t}\right)}-\frac{f_{x t}, x_{t+1}\left(X_{t}, X_{t+1}\right)}{f_{x t}\left(X_{t}\right)}\right) x g\left(X_{t}, Y_{t}, X_{t+1}\right)\right]=0
$$

where $\mathrm{g}($.$) represents a positive weight function given by \mathrm{f}_{\mathrm{xt}}^{2}\left(\mathrm{X}_{\mathrm{t}}\right)$. Diks and Panchenko (2006) modified the null hypothesis based on equation (4) as follows:

$$
\mathrm{q}=\mathrm{E}\left[\mathrm{f}_{\mathrm{xt}, \mathrm{yt}, \mathrm{xt}+1}(.) \mathrm{f}_{\mathrm{xt}}(.)-\mathrm{f}_{\mathrm{xt}}(.) \mathrm{f}_{\mathrm{xt}, \mathrm{xt}+1}(.)\right]=0
$$

The test statistic is basically the sample version of equation (7), given by the expression:

$$
\mathrm{T}_{\mathrm{n}}(\varepsilon)=\frac{\mathrm{n}-1}{\mathrm{n}(\mathrm{nn}-2)} \sum_{\mathrm{i}}^{\mathrm{n}} \widehat{\mathrm{f}}_{\mathrm{xt}}, \mathrm{yt}, \mathrm{xt}+1\left(\mathrm{x}_{\mathrm{it}}, \mathrm{y}_{\mathrm{it}}, \mathrm{x}_{\mathrm{it}+1}\right) \widehat{\mathrm{f}}_{\mathrm{xt}}\left(\mathrm{x}_{\mathrm{it}}\right)-\widehat{\mathrm{f}}_{\mathrm{xt}}, \mathrm{yt}_{\mathrm{t}}\left(\mathrm{x}_{\mathrm{it}}, \mathrm{y}_{\mathrm{it}}\right) \widehat{\mathrm{f}}_{\mathrm{xt}}, \mathrm{xt}+1\left(\mathrm{x}_{\mathrm{it}}, \mathrm{xi}_{\mathrm{t}+1}\right)
$$

Where $\widehat{f}_{z}\left(z_{i}\right)$ represents a local density estimate of each $d_{z}$-variate random vector. For $L x=L y=1$, and if the sequence of bandwidth $\varepsilon_{\mathrm{v}}=\mathrm{Cn}^{-\beta}$ where $\mathrm{c}>0$ and $\beta \in(1 / 4,1 / 3)$ then the test statistic satisfies

$$
\sqrt{\mathrm{n}}\left(\frac{\mathrm{T}_{\mathrm{n}}\left(\varepsilon_{\mathrm{n}}\right)-\mathrm{q}}{\mathrm{S}_{\mathrm{n}}} \underset{\mathrm{d}}{\longrightarrow} \mathrm{N}(0,1)\right)
$$

To put in words, the test statistic is asymptotically distributed as $\mathrm{N}(0,1)$ where Sn represents the estimator of the asymptotic variance of $T_{n}($.$) . Following Diks and Panchenko's recommendation, the present study adopted the$ one-tailed version of the test. The null hypothesis is rejected if the left-hand-side of equation (9) is large. Further details about the DP and HJ frameworks can be found in Diks and Panchenko (2006).

\section{Data and Description Statistics}

The study employs monthly data on returns for All REITs, Equity and Mortgage REITs. The data are retrieved from the website of the National Association of Real Estate Investment Trusts, Inc. (NAREIT) at 
http://www.reit.com/DataAndResearch/IndexData/FNUS-Historical-Data/Monthly-Index-Data.aspx. The data span the time period January 1972 through January 2014. To evaluate the impact of the 1992 Revenue Reconciliation Act on the relationship between bond and REITs returns, the sample period is divided into two. The first sample period runs from January 1972 through December 1992. The second sample period runs from January 1993 through January 2014. The monthly data on bond (proxied by the 10-year U.S. Treasury bond yields) are obtained from the website of the Federal Reserve Bank of St. Louis at https://research.stlouisfed.org/fred2/series/GS10.

Table 1. Summary statistics (January 1972 - January 2014)

\begin{tabular}{lcccc}
\hline & ALR & EQR & BY & MOR \\
\hline Mean & 0.92 & 1.09 & 6.86 & 0.60 \\
\hline Median & 1.14 & 1.29 & 6.65 & 0.86 \\
\hline Maximum & 30.81 & 31.02 & 15.32 & 38.4 \\
\hline Minimum & -30.23 & -31.67 & 1.53 & -24.11 \\
\hline Std. Dev. & 5.13 & 4.95 & 2.88 & 5.86 \\
\hline Skewness & -0.41 & -0.71 & 0.58 & -0.26 \\
\hline Kurtosis & 10.37 & 11.01 & 3.11 & 8.15 \\
\hline Jarque-Bera & $1177.94^{* * *}$ & $1416.61^{* * *}$ & $29.00^{* * *}$ & $573.09^{* * *}$ \\
\hline Probability & 0.00 & 0.00 & 0.00 & 0.00 \\
\hline Observations & 514 & 514 & 514 & 514
\end{tabular}

${ }^{* * *}$ Indicates significance at the $1 \%$ level. ALR $=$ All REIT returns, $\mathrm{AAA}=$ corporate bond rated by Moodys, $\mathrm{EQR}=$ Equity REIT returns, MOR $=$ Mortgage REIT returns, $\mathrm{BY}=10$-year Treasury bond yields.

The summary statistics for all, equity, mortgage REIT returns, and bond yields are presented in Table 1 . The mean values for all, equity and mortgage REIT returns are $0.92,1.09$ and 0.60 percent, respectively. The mean value for $\mathrm{BY}$ is 6.86. The minimum and maximum statistics indicate that the values of the REIT return series and bond have varied over the time period under investigation. For example, the returns for all REITs ranged from a minimum of -30.23 to a maximum of 30.81 percent. The standard deviations reveal that the returns for mortgage REIT exhibited the greatest variability $(5.86 \%)$ from the mean. In contrast, BY with a standard deviation of 2.88 percent exhibited the least deviation from the mean. The three REIT return series are negatively skewed, while BY (0.58) is positively skewed. The three REIT return series and the 10-year Treasury bond yields exhibit excess kurtosis. The Jarque-Bera statistics suggest that the null hypothesis that the series are normally distributed should be rejected at the 1 percent significance level.

Table 2 displays the Spearman's correlation coefficients between all, equity, mortgage REIT returns, and the 10-year Treasury bond yields. The results reveal that the relationships between all, equity and mortgage REIT returns are positive and statistically significant at the 1 percent level. However, the correlations between REIT returns and the 10-year Treasury bond appear to be positive in most of the cases but they are nevertheless statistically insignificant.

Table 2. Pearson correlation coefficient

\begin{tabular}{lcccc}
\hline & ALLREIT & EQREIT & BY & MOREIT \\
\hline ALLREIT & 1.00 & & & \\
\hline EQREIT & $0.93^{* * *}$ & 1.00 & & \\
\hline GS10 & 0.01 & -0.02 & 1.00 & 1.00 \\
\hline MOREIT & $0.71^{* * *}$ & $0.54^{* * *}$ & 0.02 & \\
\cline { 1 - 3 }
\end{tabular}

${ }^{* * *}$ Indicates level of significance at the $1 \%$ level. ALR $=$ All REIT returns, EQR $=$ Equity $\overline{\text { REIT returns, MOR }=}$ Mortgage REIT returns, BY $=10$-year Treasury bond yields.

\section{Empirical Results}

Prior to the application of the asymmetric causality test between the REIT return and bond series, the study tested for the order of integration using the modified ADF (DF-GLS) and the Phillips-Perron unit root procedures. The unit 
root test results are presented in Table 3. From Panel A of Table 3, it can be seen that all, equity, mortgage REIT returns have zero order of integration. A similar result is indicated is for the 10-year Treasury bond yields. The results from the modified Phillip-Perron unit root procedures (presented in Panel B of Table 3 corroborate those obtained from the DF-GLS. Taken together, the unit root test results reveal that all the series in the study are level stationary.

Table 3. Unit Root Test results (January 1972 - January 2014)

\begin{tabular}{llll}
\hline Series & t-stat & Lag(s) & $\mathbf{1 \% C V}$ \\
\hline Panel A: Modified $\boldsymbol{A D F}$ & & & -3.48 \\
\hline ALR & $-8.16^{* * *}$ & 5 & -3.48 \\
\hline EQR & $-8.44^{* * *}$ & 5 & -3.48 \\
\hline BY & $-3.87^{* * *}$ & 3 & -3.48 \\
\hline MOR & $-7.45^{* * *}$ & 5 & \\
\hline Panel B: Modified Phillips-Perron & & & -3.98 \\
\hline ALR & $-21.66^{* * *}$ & 5 & -3.98 \\
\hline EQR & $-20.84^{* * *}$ & 5 & -3.98 \\
\hline BY & $-12.12^{* * *}$ & 3 & -3.98 \\
\hline MOR & $-24.47^{* * *}$ & 5 & \\
\hline$* * * *$
\end{tabular}

${ }^{* * *}$ indicates the rejection of the null hypothesis at the 1 percent significance level.

Having determined the order of integration for the series, the study next applies the linear Granger-causality tests to ascertain the causal relationship between bonds and all, equity, and mortgage REIT returns. Tables 4A through 4C display the results from the linear Granger-causality tests. The results presented in Panel A of Table 4A reveal that there is no linear causal relationship between all REIT returns and bond yields for the full sample period running from January 1972 through October 2014. The reported $F$-statistics are not statistically significant at the conventional levels. For instance, for the null hypothesis that all REIT returns do not Granger-cause bonds, the $F$-statistic is 0.37463 with a p-value of 0.8661 . Similarly, the null hypothesis that bond yields do not Granger-cause all REIT returns could not be rejected given that the $F$-statistic is 0.34408 and the $p$-value is of 0.8661 . Again, in Panel B for the first sub-sample period running January 1972 to December 1992, the results suggest that the null hypothesis that all REIT returns do not Granger-cause bond yields should not be rejected as the reported $F$-statistic (0.49492) is not statistically significant. Similarly, the null hypothesis that bond yields do not have causal influence on all REIT returns could not be rejected. In Panel C, the results reveal that all REIT returns and bond yields do not have causal implications for each other.

Table 4A. Linear Granger Causality Test between bond yields and all REIT returns

\begin{tabular}{lll}
\hline Null Hypothesis & F-Statistic & Prob. \\
\hline Panel A: Full Sample Period January 1972 - October 2014 & & \\
\hline All REIT Returns do not Granger-cause Bond Yields & 0.37463 & 0.8661 \\
\hline Bond Yields do not Granger-cause All REIT Returns & 0.34408 & 0.8860 \\
\hline Panel B: First Sub-Sample January 1972 - December 1992 & & \\
\hline All REIT Returns do not Granger-cause Bond Yields & 0.49492 & 0.7799 \\
\hline Bond yields do not Granger-cause All REIT Returns & 0.63630 & 0.6722 \\
\hline Panel C: Second Sub-Sample January 1993 -October 2014 & & \\
\hline All REIT Returns do not Granger-cause Bond Yields & 0.62827 & 0.6783 \\
\hline Bond Yields do not Granger-cause All REIT Returns & 0.51732 & 0.7631 \\
\hline
\end{tabular}


Table 4B. Linear Granger Causality Test between bond yields and equity REIT returns

\begin{tabular}{lcc}
\hline Null Hypothesis & F-Statistic & Prob. \\
\hline Panel A: Full Sample Period January 1972 - October 2014 & 0.49356 & 0.7811 \\
\hline Equity REIT Returns do not Granger-cause Bond Yields & 0.30355 & 0.9107 \\
\hline Bond Yields do not Granger-cause Equity REIT Returns & & \\
\hline Panel B: First Sub-Sample January 1972 - December 1992 & 0.41374 & 0.8390 \\
\hline Equity REIT Returns do not Granger-cause Bond Yields & 0.55675 & 0.7331 \\
\hline Bond Yields do not Granger-cause Equity REIT Returns & & \\
\hline Panel C: Second Sub-Sample January 1993 - October 2014 & 0.68775 & 0.6331 \\
\hline Equity REIT Returns do not Granger-cause Bond Yields & 0.58884 & 0.7085 \\
\hline Bond Yields do not Granger-cause Equity REIT Returns & & \\
\hline
\end{tabular}

Table 4C. Linear Granger Causality Test between bond yields and mortgage REIT returns

\begin{tabular}{lcc}
\hline Null Hypothesis & F-Statistic & Prob. \\
\hline Panel A: Full Sample Period January 1972 - October 2014 & & \\
\hline Mortgage REIT Returns do not Granger-cause Bond Yields & 0.57906 & 0.7161 \\
\hline Bond Yields do not Granger-cause Mortgage REIT Returns & 0.46798 & 0.8002 \\
\hline Panel B: First Sub-Sample January 1972 - December 1992) & \\
\hline Mortgage REIT Returns do not Granger-cause Bond Yields & 0.21851 & 0.9544 \\
\hline Bond Yields do not Granger-cause Mortgage REIT Returns & 0.53250 & 0.7516 \\
\hline Panel C: Second Sub-Sample (January 1993 - October 2014) & \\
\hline Mortgage REIT Returns do not Granger-cause Bond Yields & 0.49429 & 0.7804 \\
\hline Bond Yields do not Granger-cause Mortgage REIT Returns & 0.44966 & 0.8133 \\
\hline
\end{tabular}

Table 4B displays the results from linear Granger causality tests between bond yields and equity REIT returns. The results presented in Panel A suggest equity REIT returns do not Granger-cause bond yields and vice versa for the full sample periods. Similar results are indicated for the first and second sub-periods. In each case, the reported $F$-statistic is statistically insignificant. For example, in the second sub-period, as reported in Panel C, the F-statistic is 0.68775 while the p-value is 0.6331 . This result implies that null hypothesis that equity REIT returns do not Granger-cause bond yields should not be rejected. Table $4 \mathrm{C}$ reports the causality test results between bond yields and mortgage REIT returns. The results displayed in Panels A through $\mathrm{C}$ of $4 \mathrm{C}$ indicate that bond yields and mortgage REIT returns do not casually affect each other. In each case, the reported F-statistic is not statistically significant at the conventional levels. Taken together, the results presented in Tables 4A through 4C suggest that bond yields and REIT returns do not have causal influence on each other. The results from the linear Granger causality could be biased if indeed the relationships between bond yieldss and REIT returns are nonlinear. Baek and Brock (1992) and Hiemstra and Jones (1994) suggest that the standard Granger causality test tend to have low power in detecting nonlinear causal relationships. To this effect, the study implements the nonlinear Granger causality test developed by Diks and Panchenko (2006). Unlike, the traditional Granger causality test, the Diks and Panchenko framework has the ability to detect nonlinear causal relationships between variables.

Table 5. BDS Linearity Test results

\begin{tabular}{|c|c|c|c|c|}
\hline Series & Stat & $M$ & P-Value & Decision \\
\hline \multicolumn{5}{|c|}{ Panel A: All REIT Returns (ALR) } \\
\hline & $5.30^{* * *}$ & 2 & 0.0000 & Reject $\mathrm{H}_{0}$ \\
\hline & $6.28^{* * *}$ & 3 & 0.0000 & Reject $\mathrm{H}_{0}$ \\
\hline & $7.70^{* * *}$ & 4 & 0.0000 & Reject $\mathrm{H}_{0}$ \\
\hline & $9.08^{* * *}$ & 5 & 0.0000 & Reject $\mathrm{H}_{0}$ \\
\hline \multicolumn{5}{|c|}{ Panel B: Equity REIT Returns (EQR) } \\
\hline 2 & $4.03^{* * *}$ & 2 & 0.0001 & Reject $\mathrm{H}_{0}$ \\
\hline 3 & $4.68^{* * *}$ & 3 & 0.0000 & Reject $\mathrm{H}_{0}$ \\
\hline 4 & $5.56^{* * *}$ & 4 & 0.0000 & Reject $\mathrm{H}_{0}$ \\
\hline 5 & $6.39^{* * *}$ & 5 & 0.0000 & Reject $\mathrm{H}_{0}$ \\
\hline
\end{tabular}

Panel C: 10-Year Treasury Constant Maturity Rate (BY) 


\begin{tabular}{ccccc}
\hline 2 & $67.35^{* * *}$ & 2 & 0.0000 & Reject $\mathrm{H}_{0}$ \\
\hline 3 & $95.86^{* * *}$ & 3 & 0.0000 & Reject $\mathrm{H}_{0}$ \\
\hline 4 & $144.92^{* * *}$ & 4 & 0.0000 & Reject $\mathrm{H}_{0}$ \\
\hline 5 & $231.63^{* * *}$ & 5 & 0.0000 & Reject $\mathrm{H}_{0}$ \\
\hline Panel E: Mortgage REIT Returns (MOR) & & & \\
\hline 2 & $6.16^{* * *}$ & 2 & 0.0000 & Reject $\mathrm{H}_{0}$ \\
\hline 3 & $6.88^{* * *}$ & 3 & 0.0000 & Reject $\mathrm{H}_{0}$ \\
\hline 4 & $7.74^{* * *}$ & 4 & 0.0000 & Reject $\mathrm{H}_{0}$ \\
\hline 5 & $8.73^{* * *}$ & 5 & 0.0000 & Reject $\mathrm{H}_{0}$ \\
\hline
\end{tabular}

${ }^{* * *}$ indicates significance at the $1 \%$ level

The study used the BDS nonlinearity procedure to determine the existence of nonlinear dependence in the data. The BDS test statistics and their accompanying p-values are presented in Table 5. The results suggest that the null hypothesis of linearity should be rejected at the 1 percent level of significance for bonds, all, equity and mortgage returns. These results indicate that series under study are nonlinear. Given the BDS test results which revealed that the variables in the study are nonlinear, the study next implemented the KSS nonlinear unit root tests. The KSS unit root tests were conducted with the raw, demeaned and the de-trended values of bonds, all, equity, and mortgage REIT returns.

Table 6. KSS Nonlinear-Stationary Test results

\begin{tabular}{llll}
\hline Series & Raw & Demeaned & De-trended \\
\hline ALR & $-7.07^{* * *}(1)$ & $-7.11^{* * *}(1)$ & $-7.06^{* * *}(1)$ \\
\hline EQR & $-6.08^{* * *}(1)$ & $-5.99^{* * *}(1)$ & $-5.98^{* * *}(1)$ \\
\hline BY & $-3.06^{* * *}(0)$ & $-3.65^{* * *}(0)$ & $-7.81^{* * *}(0)$ \\
\hline MOR & $-5.05^{* *}(3)$ & $-5.23^{* * *}(3)$ & $-5.22^{* * *}(3)$ \\
\hline Critical Values & & & -3.93 \\
\hline $1 \%$ & -2.82 & -3.48 & -3.40 \\
\hline $5 \%$ & -2.22 & -2.93 & -3.13 \\
\hline $10 \%$ & -1.92 & -2.66 &
\end{tabular}

Table 6 displays the results from the KSS nonlinear unit root tests. The results based on the raw, demeaned and detrended data reveal that the null hypothesis that the series are nonstationary should be rejected at least the 5 percent level of significance. For instance, in the of all equity REIT returns (ALR), the test statistics -7.07, -7.11 and -7.06, respectively for raw, demeaned and de-trended exceed the critical values at the 1 percent level. To check the robustness of the results from the KSS nonlinear unit root tests, the study applied the Kruse (2011) nonlinear unit root tests. The results from the Kruse (2011) procedure are presented in Table 7. The results from the Kruse (2011) unit are consistent with those obtained from the KSS nonlinear unit root tests. In all of the cases, the results in Table 7 suggest that bonds, all, equity, and mortgage REIT returns are level stationary at the 1 percent level of significance.

Table 7. Kruse (2011) Nonlinear Unit Root Test results

\begin{tabular}{llll}
\hline Series & Raw & Demeaned & De-trended \\
\hline ALR & $50.15^{* * * *}(1)$ & $50.47^{* * *}(1)$ & $49.84^{* * *}(1)$ \\
\hline EQR & $37.61^{* * * *}(1)$ & $85.98^{* * *}(1)$ & $35.96^{* * *}(1)$ \\
\hline BY & $14.88^{* * *}(0)$ & $13.41^{* * *}(0)$ & $77.99^{* * *}(0)$ \\
\hline MOR & $32.25^{* * *}(3)$ & $83.88^{* * *}(3)$ & $33.771^{* * *}(3)$ \\
\hline Critical Values & & & 17.10 \\
\hline $1 \%$ & 13.15 & 13.75 & 12.82 \\
\hline $5 \%$ & 9.53 & 10.17 & 11.10 \\
\hline $10 \%$ & 7.85 & 8.60 &
\end{tabular}


To mitigate the possible existence of nonlinearity in the in the relationships between bonds and REIT returns, this study applies the nonlinear causality test advanced by Diks and Panchenko. The test was conducted with equal lag lengths in both directions (i.e. $\mathrm{L}_{\mathrm{x}}=\mathrm{L}_{\mathrm{y}}=2 \ldots, 5$ ) and bandwidth of $\varepsilon_{\mathrm{n}}=1.5$. The results from the Diks-Panchenko nonlinear Granger causality tests are presented in Tables 8A through 8C. Table 8A displays the results from the nonlinear Granger causality test between bonds and all REIT returns for the full sample period. The results in Panel A reveal that bonds and all REIT returns have nonlinear causal influence on each other. The test statistics at the various lag lengths are statistically significant at least at the 5 percent level. Simply put, the results are supportive of the existence of bi-directional nonlinear causality between all REIT returns and bonds for the full sample period. Panel B of Table 8A presents the results for the nonlinear Granger causality test between bonds and all REIT returns for the first sub-period running from January 1972 to December 1992. The results indicate that bonds and all REIT returns do not have nonlinear causal effect on each other. In each case, the $t$-statistic is statistically insignificant at the conventional levels. However, the results presented in Panel C for the second sub-period (i.e. January 1993 through October 2014) reveal that nonlinear Granger causality runs from all REIT returns to bonds. At lags 4 and 5, the test statistics are statistically significant at the 5 percent level of significance.

Table 8A. Nonlinear Granger Causality Test between bond yields and all REIT returns

\begin{tabular}{|c|c|c|c|c|}
\hline & $\mathrm{BY} \nrightarrow \mathrm{ALR}$ & & \multicolumn{2}{|c|}{$\mathrm{ALR} \nrightarrow \mathrm{BY}$} \\
\hline $\mathbf{L}_{\mathbf{x}}=\mathbf{L}_{\mathbf{y}}$ & t-Stat & P-Value & t-Stat & P-Value \\
\hline \multicolumn{5}{|c|}{ Panel A: Full Sample Period January 1972 - October 2014} \\
\hline 2 & $1.772 * *$ & 0.0381 & $1.760 * *$ & 0.03924 \\
\hline 3 & $1.737 * *$ & 0.04116 & $1.900 * *$ & 0.02874 \\
\hline 4 & $1.430^{*}$ & 0.07636 & $2.379 * * *$ & 0.00869 \\
\hline 5 & $1.671 * *$ & 0.04738 & $2.107 * *$ & 0.01757 \\
\hline \multicolumn{5}{|c|}{ Conclusion: bi-directional nonlinear causality between BY and ALR } \\
\hline \multicolumn{5}{|c|}{ Panel B: First Sub-Sample January 1972 - December 1992} \\
\hline 2 & 1.121 & 0.13108 & -0.004 & 0.50141 \\
\hline 3 & 1.009 & 0.13807 & -0.782 & 0.78287 \\
\hline 4 & 0.795 & 0.21338 & 0.209 & 0.41737 \\
\hline 5 & 0.989 & 0.16141 & -0.296 & 0.61624 \\
\hline \multicolumn{5}{|c|}{ Conclusion: No nonlinear causality } \\
\hline \multicolumn{5}{|c|}{ Panel C: Second Sub-Sample (January 1993 - October 2014} \\
\hline 2 & 0.011 & 0.49552 & 1.198 & 0.11555 \\
\hline 3 & 0.352 & 0.36257 & 0.994 & 0.16001 \\
\hline 4 & 0.751 & 0.22622 & $1.834 * *$ & 0.03336 \\
\hline 5 & 0.934 & 0.17522 & $1.814^{* *}$ & 0.03481 \\
\hline \multicolumn{5}{|c|}{ Conclusion: unidirectional nonlinear causality from ALR to BY } \\
\hline
\end{tabular}

Table 8B presents the results for nonlinear Granger causality test between bonds and equity REIT returns. The results in Panel A, for the full sample period show that bonds and equity REIT returns have nonlinear causal influence on each other. The test statistics are all statistically significant at least at the 10 percent level. These results provide evidence of the existence of bi-directional nonlinear causal relationship between bonds and equity REIT returns for the full sample period. The results in Panel B, show evidence of unidirectional nonlinear causality running from bonds to equity REIT returns for the first sub-period. However, the results in Panel C for the second sub-period reveal that nonlinear causality runs from equity REIT returns to bonds. These results are consistent with Glascock et al. (2000) who contend found REITs behave more like stocks and less like bonds following the structural changes including the 1993 Revenue Reconciliation Act, which took place in the early 1990s. 
Table 8B. Nonlinear Granger Causality Test between bond yields and equity REIT returns

\begin{tabular}{|c|c|c|c|c|}
\hline & $\mathrm{BY} \nrightarrow \mathrm{EQR}$ & & \multicolumn{2}{|c|}{$\mathrm{EQR} \nrightarrow \mathrm{BY}$} \\
\hline $\mathbf{L}_{\mathbf{x}}=\mathbf{L}_{\mathrm{y}}$ & t-Stat & P-Value & t-Stat & P-Value \\
\hline \multicolumn{5}{|c|}{ Panel A: Full Sample Period January 1972 - October 2014} \\
\hline 2 & $2.077 * *$ & 0.01892 & $1.288^{*}$ & 0.09887 \\
\hline 3 & $2.263 * * *$ & 0.01181 & $1.867^{* *}$ & 0.03098 \\
\hline 4 & $2.177 * *$ & 0.01474 & $2.064 * *$ & 0.01949 \\
\hline 5 & $2.048^{* *}$ & 0.02029 & $1.978^{* *}$ & 0.02396 \\
\hline \multirow{2}{*}{\multicolumn{5}{|c|}{$\begin{array}{l}\text { for } \varepsilon=1.50 \quad \text { Conclusion: bi-directional nonlinear causality between BY and EQR } \\
\text { Panel B: First Sub-Sample Januarv } 1972 \text { - December } 1992\end{array}$}} \\
\hline & & & & \\
\hline 2 & $1.367^{*}$ & 0.08582 & 0.141 & 0.44391 \\
\hline 3 & $1.839^{* *}$ & 0.03295 & 0.050 & 0.48025 \\
\hline 4 & $1.975^{* *}$ & 0.02415 & 0.768 & 0.22129 \\
\hline 5 & $1.763^{* *}$ & 0.03892 & 0.618 & 0.73186 \\
\hline \multicolumn{5}{|c|}{ Conclusion: Unidirectional nonlinear causality from $\mathrm{BY}$ to $\mathrm{EQR}$} \\
\hline \multicolumn{5}{|c|}{ Panel C: Second Sub-Sample (January 1993 - October 2014} \\
\hline 2 & 0.174 & 0.43113 & 0.183 & 0.11845 \\
\hline 3 & 0.497 & 0.30942 & 1.144 & 0.12636 \\
\hline 4 & 0.718 & 0.23634 & $1.819^{* *}$ & 0.03444 \\
\hline 5 & 0.874 & 0.19118 & $1.722 * *$ & 0.04256 \\
\hline for $\varepsilon=1.50$ & Conclusion: $\mathrm{u}$ & al nonline & om EQR t & \\
\hline
\end{tabular}

Table 8C displays the results from the nonlinear Granger causality tests between bonds and mortgage REIT returns. From Panel A, of Table 8C, it can be observed that nonlinear causality runs from mortgage REIT returns to bonds. The test statistics (1.594 and 1.777) are statically significant at the 10 and 5 percent, respectively at the 4 and 5 lags. These results provide evidence in support of the existence of a unidirectional nonlinear causal relationship between bond yields and mortgage REIT returns for the full sample period. However, for the two sub-periods, the results failed to provide evidence of nonlinear causality between bond yields and mortgage REIT returns.

Table 8C. Nonlinear Granger Causality Test between bond yields and mortgage REIT returns

\begin{tabular}{|c|c|c|c|c|}
\hline \multicolumn{3}{|c|}{$\mathrm{BY} \nrightarrow \mathrm{MOR}$} & \multicolumn{2}{|c|}{$\mathrm{MOR} \nrightarrow \mathrm{BY}$} \\
\hline $\mathbf{L}_{\mathbf{x}}=\mathbf{L}_{\mathbf{y}}$ & $t-$ Stat & P-Value & t-Stat & P-Value \\
\hline \multicolumn{5}{|c|}{ Panel A: Full Sample Period January 1972 - October 2014} \\
\hline 2 & 0.473 & 0.31796 & -0.760 & 0.77643 \\
\hline 3 & 0.935 & 0.17477 & -0.075 & 0.52985 \\
\hline 4 & 0.643 & 0.26016 & $1.594 *$ & 0.05549 \\
\hline 5 & 0.819 & 0.20637 & $1.777 * *$ & 0.03779 \\
\hline \multicolumn{5}{|c|}{ Conclusion: unidirectional nonlinear causality from MOR to BY } \\
\hline \multicolumn{5}{|c|}{ Panel B: First Sub-Sample January 1972 - December 1992} \\
\hline 2 & 0.327 & 0.37175 & 0.271 & 0.39337 \\
\hline 3 & 0.378 & 0.35276 & 0.558 & 0.28841 \\
\hline 4 & 0.776 & 0.21878 & 0.848 & 0.19829 \\
\hline 5 & 1.223 & 0.11066 & 0.443 & 0.32884 \\
\hline
\end{tabular}

for $\varepsilon=1.50 \quad$ Conclusion: No nonlinear causality between BY and MOR

\begin{tabular}{ccccc}
\hline Panel C: Second Sub-Sample January & 1993 - October 2014 & & \\
\hline 2 & -2.367 & 0.99102 & -2.317 & 0.98974 \\
\hline 3 & -1.354 & 0.91212 & -1.793 & 0.96353 \\
4 & -0.689 & 0.75455 & 0.103 & 0.45881 \\
\hline 5 & -0.584 & 0.72030 & 0.272 & 0.39271
\end{tabular}

for $\varepsilon=1.50 \quad$ Conclusion: No nonlinear causality between EQR and BY

${ }^{* * *},{ }^{* *}$ and ${ }^{*}$ indicate significance at the $1 \%, 5 \%$ and $10 \%$ level, respectively. BY $=10$-Year Treasury Constant Maturity Rate, MOR = Mortgage REIT returns 


\section{Summary and Implications}

This paper has examined relationship between bond yields and REIT returns using linear and nonlinear Granger causality tests for the time period running from January 1972 through October 2014. In particular, the paper used the standard VAR models to test for linear Granger causality between bond and REIT returns. To test for the nonlinear Granger causality between bond and REIT returns, the study applied the test developed by Diks and Panchenko (2006). The study divided the sample period into two in order to assess the effect of the 1992 Revenue Reconciliation Act on the relationship between bonds and REIT returns. The first sub-period started from January 1972 to December 1992. The second sub-period started from January 1993 through January 2014.

The results from the various unit root tests indicate that the bond and REIT returns series are stationary processes. The linear Granger causality test results indicate that bond yields and REIT returns do not have causal influence on each other in the full sample and the two sub-periods. However, the results from the Diks-Panchenko nonlinear causality test indicate that all REIT returns and bond yields have causal influence on each other for the full sample period. Similarly, the results show that equity REIT returns and bond yields causally affect each other for the full sample period. However, the results further showed evidence supportive of unidirectional nonlinear causality from mortgage REIT returns to bond yields for the full sample period. The existence of nonlinear causality in least one direction for the full sample period suggests that diversification benefits cannot be attained by combining REITs and bonds in a portfolio.

For the first sub-period, the results revealed that all and mortgage REIT returns do not have nonlinear causal influence on bond yields and vice versa. However, there was evidence of nonlinear causality running from equity REIT returns to bond yields in the first sub-period. For the second sub-period, the results provide support for the existence of nonlinear causality from all and equity REIT returns to bond yields. However, the results failed to provide evidence of nonlinear causality between mortgage REIT returns and bond yields for the second sub-period which follows the introduction of the 1992 Revenue Reconciliation Act. This finding implies that it is possible for investors to attain some diversification benefits by combining mortgage REITs and bonds in their portfolios for the time period following the establishment of the 1992 Revenue Reconciliation Act.

\section{References}

Baek, E., \& Brock, W. (1992). A general test for non-linear Granger causality: Bivariate model, Working paper. Iowa State University and University of Wisconsin, Madison, WI. Retrieved May 16, 2015, from http://www.ssc.wisc.edu/ wbrock/Baek\%20Brock\%20Granger.pdf

Bekiros, S.D., \& Diks, C.G.H. (2008). The relationship between crude oil spot and futures prices: cointegration, linear and nonlinear causality. Energy Economics, 30, 2673-2685. $\mathrm{http}: / / \mathrm{dx}$.doi.org/10.1016/j.eneco.2008.03.006

Brock, W.A., Dechert, W.D., \& Scheinkman, J.A. (1987). A test for independence based on the correlation dimension, Unpublished manuscript. Madison: University of Wisconsin. Retrieved from www.princeton.edu/ joses/wp/BDS.pdf

Brock, W.A., Dechert, W.D.,. Scheinkman, J.A., \& LeBaron, B. (1996). A test for independence based on the correlation dimension. Econometric Reviews, 15, 197-235. http://dx.doi.org/10.1080/07474939608800353

Brounen, D., \& Eichholtz, P. (2003). Property, Common Stocks, and Property Shares. Increased potential for diversification. The Journal of Portfolio Management, Special Issue, 129-137. http://dx.doi.org/10.3905/jpm.2003.319914

Cauchie, S., \& Hoesli, M. (2004). The Integration of Securitized Real Estate and Financial Assets. University de Geneve, Research Paper. 111. http://dx.doi.org/10.2139/ssrn.559004

Chiang, M., Tsai, I., \& Sing, T. (2013). Are REITs a good shelter from financial crises? Evidence from the Asian markets. Journal of Property Investment and Finance, 3(31), 237-253. http://dx.doi.org/10.1108/14635781311322210

Ciochetti, B., Craft, T., \& Shilling, J. (2002). Institutional investors' preference for REIT stocks. Real Estate Economics, 30(4), 567-593. http://dx.doi.org/10.1111/1540-6229.t01-1-00051

Dickey, D., \& Fuller, W. (1981). The likelihood ratio statistics for autoregressive time series with a unit root. Econometrica, 49, 1057-1072. Retrieved May 16, 2015, from http://www.u.arizona.edu/ rlo/readings/278800.pdf

Dickey, D.A., \& Fuller, W.A. (1979). Distribution of the estimators for autoregressive time series with a unit root. Journal of the American Statistical Society, 75, 427-431. Retrieved May 16, 2015, from http://www.deu.edu.tr/userweb/onder.hanedar/dosyalar/1979.pdf 
Diks, C., \& Panchenko, V. (2006). A new statistic and practical guidelines for nonparametric Granger causality testing. Journal of Economic Dynamics and Control, 30, 1647-1669. http://dx.doi.org/10.1016/j.jedc.2005.08.008

Elebash, C.C., \& Christianses, W.A. (1989). State pension funds: What is their future in real estate? Journal of Real Estate Research, 4, 71-80. Retrieved May 16, 2015, from http://pages.jh.edu/jrer/papers/pdf/past/vol04n02/v04p071.pdf

Ennis, R.M., \& Burik, P. (1991). Pension fund real estate investment under a simple equilibrium pricing model. Financial Analyst Journal, 47, 20-30. http://dx.doi.org/10.2469/faj.v47.n3.20

Fogler, H.R. (1984). 20\% in Real Estate: Can theory justify it? Journal of Portfolio Management, 7, 6-13. http://dx.doi.org/10.3905/jpm.1984.6

Glascock, J., Lu, C., \& So, R. (2000). Further evidence on the integration of REIT, bond and stock returns. Journal of Real Estate Finance and Economics, 20, 177-194. http://dx.doi.org/10.1023/A:1007877321475

Granger, C.W.J. (1969). Investigating causal relations by econometric models and cross-spectral Methods. Econometrica, $37, \quad 424-438 . \quad$ Retrieved $\quad$ from http://links.jstor.org/sici?sici=0012-9682\%28196908\%2937\%3A3\%3C424\%3AICRBEM\%3E2.0.CO\%3B2-L

Hiemstra, C., \& Jones, J.D. (1994). Testing for linear and nonlinear Granger causality in the stock price-volume relation. Journal of Finance, 49, 1639-1664. http://dx.doi.org/10.2307/2329266

Hoesli, M., Lekander, J., \& Witkiewicz, W. (2004). International evidence on real estate as a Portfolio Diversifier. Journal of Real Estate Research, 26, 161-206. Retrieved from http://ssrn.com/abstract=954729

Kallberg, J.G., Liu, C.H., \& Greig, W.D. (1996). The role of real estate in the portfolio allocation process. Real Estate Economics, 24, 359-377. Retrieved from http://ssrn.com/abstract=9140

Kapetanios, G., Shin, Y., \& Snell, A. (2003). Testing for a unit root in the nonlinear STAR Framework. Journal of Econometrics, 112, 359-379. http://dx.doi.org/10.1016/S0304-4076(02)00202-6

Kleiman, R.T., Payne, J.E., \& Sahu, A.P. (2002). Random walks and market efficiency: evidence from international real estate markets. Journal of Real Estate Research, 24, 279-298. Retrieved May 16, 2015, from http://pages.jh.edu/jrer/papers/pdf/past/vol24n03/04.279_298.pdf

Kruse, R. (2011). A new unit root test against ESTAR based on a class of modified statistics. Statistical Papers, 52, 71-85. http://dx.doi.org/10.1007/s00362-009-0204-1

Newell, G., \& Webb, R.J. (1996). Assessing risk for international real estate investments. Journal of Real Estate Research, 11, 103-116. Retrieved May 16, 2015, from http://pages.jh.edu/jrer/papers/pdf/past/vol11n02/v11p103.pdf

Olaleye, A., \& Ekemode, B. (2014). Integration between real estate equity and non-real estate Equity. Journal of Property Investment and Finance, 3(32), 244-255. http://dx.doi.org/10.1108/JPIF-10-2013-0063

Seiler, M., Webb, J., \& Myer, F.N. (1999). Diversification issues in real estate investment. Journal of Real Estate Literature, 7, 163-179. http://dx.doi.org/10.1023/A:1008741320860

Serrano, C., \& Hoesli, M. (2012). Fractional co-integration analysis of securitized real estate. Journal of Real Estate Finance and Economics, 44, 319-338. http://dx.doi.org/10.1007/s11146-009-9231-x

Tsai, M., \& Chiang, S. (2013). The asymmetric price adjustment between REIT and stock markets in Asia-Pacific markets. Economic Modelling, 32(2013), 91-99. http://dx.doi.org/10.1016/j.econmod.2012.12.013

Westerheide, P. (2006). Co-integration of real estate stocks and REITs with common stocks, bonds and consumer price inflation: an international comparison. Discussion Paper No. 06-057, Center for European Economic Research. Retrieved May 15, 2015, from http://ftp.zew.de/pub/zew-docs/dp/dp06057.pdf

Wilson, P., \& Okunev, J. (1999). Long-term dependencies and long-run non-periodic co-cycles: real estate and stock markets. Journal of Real Estate Research, 18, 257-278. Retrieved May 16, 2015, from http://pages.jh.edu/jrer/papers/pdf/past/vol18n02/v18p257.pdf

Yunus, N. (2012). Modelling relationships among securitized property markets, stock markets, and macroeconomic variables. Journal of Real Estate Research, 2(34), 127-156. Retrieved May 16, 2015, from http://pages.jh.edu/jrer/papers/pdf/past/vol34n02/01.127_156.pdf

Yunus, N. (2013). Dynamic interactions among property types: international evidence based on cointegration tests. Journal of Property Investment and Finance, 2(31), 135-159. http://dx.doi.org/10.1108/14635781311305372

Ziobrowski, B.J., \& Ziiobrowski, A.J. (1997). Higher real estate risk and mixed asset portfolio performance. Journal of Real Estate Portfolio Management, 3(2), 107-115. http://ares.metapress.com/content/g72856473128g850/ 